ture, an increase instead of decrease at higher stations. $\mathrm{He}$ brings forward a long array of figures supporting this conclusion, especially for sunrise effects in 1883 , as seen from Säntis $(2467$ metres), in North-East Switzerland, in the bend of the Rhine. Stations to the east-Munich ( 528 metres) and Hohen Peissenberg ( 994 metres) are taken for observations on temperature and relative humidity. The last place is about 35 miles south-west of Munich ; both may be considered as beneath the sky region producing glows at Säntis. As difference of temperalure is the most decisive comparison, his tables are here reduced to a series showing the difference of Hohen Peissenberg returns from Munich, in degrees Centigrade. In some cases one or two other returns are also added, reduced in like manner. Normally, allowing for difference of height, Hohen Peissenberg should register $2^{\circ} .5$ below Munich.

The final set of observations refer to some of the earlier afterglows. The greater anomaly with greater elevation (increases of $5^{\circ} \cdot 2,10^{\circ} \cdot 6,12^{\circ} \cdot 2$; and $17^{\circ} \cdot \mathrm{I}$ respectively in the figures given) is very suggestive. The reason of the non-agreement in May has already been stated.

Except the last, these observations refer to ordinary sunrise effects, but the only difference between them and the recent glows is considered to be that the latter occur by reflection at a higher level and in a more finely attenuated haze, thus giving the richer effects. The presence of such a haze with the glows was a matter of very common observation.

The question, of course, requires further consideration, especially with respect to observations of the recent glows. Besides this connection with a warm stratum of air, Prof. Kiessling finds another, almost as general, with barometric maxima, as was noticed with the similar phenomena in $\mathrm{r} 88 \mathrm{r}$.

Referring, in his concluding paragraph, to the connection of the glows with the Krakatoa eruption, Prof. Kiessling writes that the thousand or so records of their geographical distribution, now in his hands, "show a perfectly continuous spread of the anomalous glows, and of the diffraction phenomena of Bishop's Ring dating from August 26, I $88_{3}$, and spreading from the Straits of Sunda as a centre over the tropical and temperate zones."

J. EdMund Ciark

\section{A CENTURY OF SCIENCE IN BENGAL}

$\mathrm{I} \mathrm{T}$ was a happy idea of the Council of the Asiatic Society of Bengal to commemorate the completion of a century of the Society's existence by publishing a review of the progress made and the services rendered to knowledge by the institution. ${ }^{1}$ The idea of a learned society composed of Europeans in India studying the country and communicating to each other at periodical meetings the results of their researches, arose first in the fertile brain of Sir William Jones, who was inclge in the Supreme Court at Fort William, and who delivered, on January 15,1784 , to about thirty members of the European community of Calcutta, a "Discourse on the Institution of a Society for Inquiring into the History, Civil and Natural, the Antiquities, Arts, Sciences, and Literature of Asia." As a result of this discourse, the "Asiatick Socicty," the parent of all such societies, was founded. Its motto, which is taken from Sir William Jones's discourse here referred to, is this: "The bounds of its investigations will be the geographical limits of Asia, and within these limits its inquiries will be extended to whatever is performed by man or produced by nature." After many vicissitudes it has just completed its hundredth year, and the record of its work forms the large volume just mentioned. This is divided into three parts : first, a history of the Society, by Dr. Mitra ; its work in archæology, history, and literature, hy Dr. Hœrnle ; and the work in natural science, by Baboo P. N. Bose. The change which has come over the face of India in the course of a century could hardly be better marked than by the fact that two out of the three parts into which the volume is divided-one of these being on natural science-are written by native gentlemen. In the history of the Society we notice that in 1808 a resolution was proposed by Dr. Hare and seconded by Dr. Leyden (frequently referred to in Lockhart's "Life of Scott"), "that a Committee be appointed for the purpose of physical investigations, the collection of facts, specimens, and correspondence with individuals whose situations in this country may be favourable for such discussions and investigations." It was then agreed to provide two committees-

1 "Centenary Review of the Asiatic Society of Bengal, I 784 to $188_{3}$." Published by the Society, Calcutta. Thacker, Spink, and Co., ${ }_{1885}$. one for science, the other for literature; twenty years later, in 1828 , a committee was appointed "to promote geological researches, working under the rules then in force for the Physical Committee," and at the same time the published Transaitions of the Society were divided into two parts, one devoted to physical, the other to literary subjects. Nearly twenty years Jater the whole of the work of the Socicty was delegated to six committees, one having charge of zoology and natural history, another of geology and mineralogy, and a third of meteorology and physics. The establishment of a museum dich not occur to the founder, but curiosities were constantly coming in from members, and in 1796 it was proposed to give these a suitable house. In I8I4 Dr. Wallich proposed the formation of a museum, and offered duplicates from his own collections, as well as his services in arranging it, and a museum was accordingly started. The story of the growth of the various sections of the Natural History Museum is told by Dr. Mitra. On the whole it is one of great progress, although financial difficulties beset the museum at first. But as soon as the Society became able to pay for scientific curators all went well. In 1865 the Society's zoological, geological, and archæ?logical collections were marle over to the Government of India for the public museum in Calcutta. A writer in the Calcutta Review, speaking of the Society's exertions for the establishment of the national museum, said: " $\mathrm{Had}$ it done nothing else to promote science during the last ten years, it would have entitled itself to the gratitude of posterity for the vigour with which it has prosecuted to success a project fraught with so much public usefulness." The earlier volumes of the Socicty's Transactions, published unfer the title " Asiatick Researches," created a sensation in the literary and scientific world in Europe. A French translation was speedily published, with notes on the scientific portions by no lesser hands than Cuvier, Lamarck, Delambre, and Olivier. Of the work of the Society in peserving Sanskrit MSS., in translating and publishing various works from the native languages, and other valuable services to literature, Dr. Mitra speaks at length. Amongst the publications, apart from the papers, we notice many of scientific interest, such as catalogues of various sections of the museum, of the mammals and birds of Burmah, of Indian lepidoptera, besides translations of numerous works of Hindoo science. In summing up at the conclusion of his historical sketch the benefits conferred on India and the world by the Society during its hundred years of existence, Dr. Mitra sums up its scientific work (apart from papers, and published volumes above referred to) thus: "It got up an archæological and ethnological m:seum of considerable extent, a geological museum rich in meteorites and Indian fossils, and a zoological museum all but complete as re gards the avifauna of India."

The long review of the work of the Society in natural science is, as already mentioned, written by Baboo Bose. His method is to take the various branches of science in succession, such as mathematical and physical science, geology, zoology, botany, geography, ethnology, and chemistry, and to describe under sub-heads the paper on these subjects contributed to the Transactions of the Society, together with a brief biographical sketch of the more cclebrated or prolific authors. At the end we get a classified index of all the scientific papers, an alphabetical list according to the author's names being given at the conclusion of the first part. Amongst the latter we notice many whose names are familiar as contributors to NATURE. In the early years of the Society, and down to 1828 , the scientific contributions to the Society's Proceedings were almost wholly connected with some branch of pure or mixed mathematics, for most of the men who went out to India, especially in the scientific branches of the military service, had been well grounded in this subject. The section on the investigations into the mathematical science of the Hindoos is of great interest. Sir William Jones put before the Society from the outset the object of studying these sciences, and he set the example himself, but the initial difficulty was to find any native capable of assisting him. Baboo Bose records that, although ample stipends were offered by Sir William Jones to any Hindoo astronomer who could name in Sanskrit all the constellations which he would point out, and to any Hindoo physician who could bring him all the plants mentioned in Sanskrit books, he was assured by the Brahmans whom he had commissioned to search for such instructors, that no Pundit in Bengal even pretended to possess the knowledge he required. Geology and mineralogy flourished in the Society from the commencement, while zoology was at first unduly depressed and discouraged owing 
to the aversion of Sir William Jones to zoological studies, and it was only about 1828 that the papers of Dr. Falconer, Col. Tickell, and others began to occupy an important position on behalf of zoology in the Society's transactions. With Indian botany, geography, and ethnology are connected many name; of world-wide fame. With regard to chemistry, it may be said practically there is no chemical research in the Society's publications. Chemistry, as Baboo Bose explains, can only be studied in the laboratory, and until recently India had but few laboratories, and few competent men with leisure to devote to the subject. A curious statement, by the way, creeps into the account of Mr. Piddington, who studied Indian storms, and gave an account of every cyclone in the East between 1839 and 1851 . Baboo Bose says his experience was most varied, and then quotes the following from some unnamed source:- "He was one of the few who escaped from the massacre of Amboyna." Now, as the massacre of Englishmen by the Dutch Governor of $\Lambda$ mboyna took place in $1622, \mathrm{Mr}$. Piddington, if he was observing storms in India in 1850, could hardly have been in the Eastern Archipelago two centuries and a quarter previously. Many other portions of this volume, such as the chapters on coins, on ancient Indian alphabets, on the study of the languages and literature of India, and on the study of Indian antiquities, are of deep interest, but we have confined ourselves to the chapters on natural science.

The dominant feeling produced by an examination of this volume is one of satisfaction that so much has been done by this single society towards investigating the past and the present of (or, in the words of Sir William Jones, "man and nature in ") our great dependency. For the most part this has been done by private indiviàuals, but on more than one critical occasion the directors of the East India Company, in accordance with their generous traditions, came to the aid of the Society with large contributions; otherwise there appeared no way out of the difficulty except the dissolution of the Society and the abandonment of the works in which they were engaged. If this were the place it would be interesting to compare this method of practically leaving everything to private initiative, with that adopted by the French in Indo-China, of the Government undertaking a series of literary, artistic, and scientific investigations through competent specialists into a new possession. Notwithstanding the great and marked success of the Asiatic Society of Bengal, the French plan has advantages which cannot be overlooked.

\section{UNIVERSITY AND EDUCATIONAL INTELLIGENCE}

CAmbridge.-Among the more noticeable Natural science Courses this term are Prof. Dewar's on Dissociation and Thermal Chemistry ; Prof. Newton's, on Evolution in the Animal Kingdom; Dr. Gadow's on Human Embryology; Dr. Vines's, on the Physiology of Plants; and Prof. Macalister's, on the Peripheral Nervous System.

Prof. Hughes is lecturing on Methods of Geological Surveying ; Dr. R. D. Roberts, on Principles of Geology ; Mr. Marr, on Elementary Stratigraphy; Mr. T. Roberts, on Palæontology; and Mr. Hawker, on Elementary Petrology ; all at the Woodwardian Museum.

Prof. Roy is lecturing on General Pathology, and also conducting a Practical Course in Morbid Anatomy and Histology.

Prof Stokes is lecturing on Hydrodynamic; ; Prof. Cayley, on Higher Algebra; Prof. Darwin, on Orbits and Perturbations; Mr. Glazebrook, on Waves and Sound; Mr. Hobson, on Planetary Theory; Mr. Macaulay, on Theory of Structures; and Mr. Forsyth on Abel's Theorem. Numerous other courses on higher mathematics, open to the University, are being given by college lecturers.

We are glad to notice that Mr. A. Sheridan Lea, M.A., Lecturer on Physiology, and formerly Scholar, of Trinity College, has been elected to a Fellowship at Gonville and Caius College. Mr. Lea's work in connection with Prof. Michael Foster's "Text-Book of Physiology" is well known. Mr. Lea was placed in the First Class in the Natural Science Tripos in 1875, and has since been continuously engaged in the University teaching of Physiology.

Dr. S. Richemann has been appointed assistant to Prof. Dewar, Jacksonian Professor.

Messrs. E. W. Hobson and A. R. Forsyth are appointed
Moderators, and Mr. C. H. Prior Examiner, for the next Mathematical Tripos.

King's College offers a Vintner Exhibition of $70 l$. per annum for Natural Science. The examination begins on December Io. St. John's College offers several scholarships, exhibitions, and sizarships for competition on December Io. Candidates may offer any of the subjects of the Natural Sciences Tripos except Mineralogy, and may be elected on the ground of special proficiency in one only. Particulars will be furnished by the tutors.

A joint examination for Natural Science Scholarships at Emmanuel, Christ's, and Sidney Sussex Colleges will be held on January 5, I886, and following days. The subjects are Chemistry, Physics, Elementary Biology, Geology, and Mineralogy. Further particulars will be given by the tutors of either colleg.

Out of the 875 freshmen whose names have appeared in the preliminary lists, about 104 have announced their intention of studying medicine in the University. A few more may be added when the results of the October Previous Examination are known. The Anatomy School is attended by over 130 students, for whom an exceptionally abundant supply of dissecting material is in hand. The Demonstration Lectures have to be repeated from lack of room; indeed, the necessity for increased accommodation in this department is becoming extremely urgent.

LONDON.-We have received a circular stating that "In view of the adjourned extraordinary meeting of Convocation (of London University) to be held on Tuesday, November 3 , a number of graduates met on Wednesday last to consider the proposed scheme for the establishment of a Teaching University for London. As the result of their deliberations it was thought desirable that attention should be called to some of the more striking objections to the proposed scheme; and that, having regard to the grave importance of the questions to be submitted to the members of Convocation affecting the very existence of the University as at present constituted, they should be especially requested to attend on Tuesday next, and to give their support to Mr. Bone's amendment, to receive the report submitted by Lord Justice Fry, without adopting it " in bloc.' Should this amendment be carried, the following reso. lutions, expressing what is believed to be the feeling of the majority of the graduates, will be moved:-(I) "That Convocation, whilst affirming the general principles of the desirableness of bringing the teachers and the examiners of the University into closer relationship with one another and with the Senate, and of modifying the constitution of the Senate in accordance with the previous recommendations of Convocation, and without giving to the teachers an undue share of representation on the governing body of the University, refers back the scheme to the Special Committee for further consideration.' (2) 'That the number of members on the Special Committee be increased by one-half.' "

\section{SOCIETIES AND ACADEMIES SyDNEY}

Linnean Society of New South Wales, July 29.-The following papers were read:-A monograph of the Australian sponges, part 5, the Auleninæ, by R. von Lendenfeld, Ph.D. Several sponges from various localities in the Australian region have been included by the author in this new sub-family, the members of which are characterised by a very peculiar structure not met with in any other sponges. The new sub-family Aulenince is placed in the family Spongidæ, and consists of the two new genera Aulena and Halme, with three species in all. The anatomy and histology of these is accurately described and illustrated by numerous plates. The Auleninæ form honeycombed or complicated reticulate structures; the cavities form a kind of vestibule and are simple in Halme, where an outer lamella surrounds the whole sponge, or subdivided into numerous small compartments, as in Aulena, where no outer lamella exists. Into the system of Vestibule-Lacunæ both the inhalent and the exhalent canals of the sponge open. The skeleton of Halme is composed of thick main fibres rich in sand, thin, simple and clean connecting fibres, and a hard cortex of sand cemented with spongiolin. The skeleton of Aulena is very peculiar. It consists of a regular network of fine horny threads in the joining points of which large sand grains are found. In the membranes of the Vestibule-Lacunæ of this genus nervous elements, 